\title{
Change in Climate Extremes and Pan Evaporation Influencing Factors over Ouémé Delta in Bénin
}

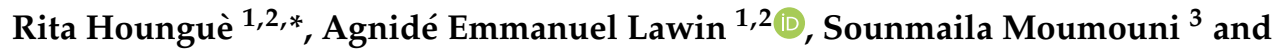 \\ Akambi Abel Afouda 1,2 \\ 1 Laboratory of Applied Hydrology (LHA), National Water Institute (INE), 01 BP: 4521 Cotonou, Bénin; \\ ewaari@yahoo.fr \\ 2 West African Science Service Center on Climate Change and Adapted Land Use (WASCAL), National Water \\ Institute (INE), 01 BP: 4521 Cotonou, Bénin; aafouda@yahoo.fr \\ 3 Higher Teachers' Training School of Natitingou, Bénin; sgonrouwa@yahoo.fr \\ * Correspondence: hounguerita@gmail.com; Tel.: +229-662-635-34
}

Received: 26 October 2018; Accepted: 18 December 2018; Published: 24 December 2018

\begin{abstract}
This work focuses on trend analysis of rainfall, evaporation, temperature, relative humidity, wind speed, and sunshine duration over the Ouémé Delta in Bénin. Eight temperature based indices and fifteen rainfall based indices are computed from 1960 to 2016. Moreover, maximum 1, 2, 3, 5, and 10 days precipitation indices were computed at the monthly scale. Trends are detected at 0.05 confidence level, using a combination of Mann-Kendall and prewhitened Mann-Kendall test. Partial correlation and stepwise regression are used to detect the set of meteorological variables that influence pan evaporation in Ouémé Delta. Results showed intensification of heavy rainfall over Ouémé Delta. Moreover, a significant increasing trend is detected in temperature. As consequence, diurnal temperature significantly decreases as proof of the global warming. Average pan evaporation showed a significant slither increasing trend over the area. Change in pan evaporation can be explained by wind speed and sunshine duration that hold almost $50 \%$ of pan evaporation variance. As future temperature is going to be increasing, pan evaporation may increase considerably. So, adaptation measures have to be reinforced in the Ouémé Delta area where farmer are used to rainfed agriculture for food security. Moreover, Ouémé Delta plan have to be developed for it resources sustainability.
\end{abstract}

Keywords: Climate extremes; pan evaporation; trends; Ouémé Delta

\section{Introduction}

Quantifying impacts of changes in climatic patterns over natural resources in a given region is prominent at area level where micro climate is significant. This is important in the development of planning and management of water resources, to cater for everyday demand and supply of users, especially in developing countries where the economy is based on rainfed agriculture [1].

In Africa, a gradual return to wetter conditions is observed in Sahelian and Soudanian areas since the 1990s [2]. The same situation is reported since early 2000s across Algeria and Tunisia and from 2008 in Morocco by Nouaceur et al. [3]. There are contrasting trends throughout seasonal variations of rainfall. Nevertheless, extreme rainfall is declining in Cote d'Ivoire [4] and annual precipitationtend to reduce in Nigeria [5]. No significant trends were detected in Ghana [6].

In Bénin, annual total precipitation, annual number of wet days and maximum 30 days rainfall present a significant decreasing trend [7]. Interpolated change in heavy rainfall of different return periods revealed an east-west gradient from negative to positive along the lower Ouémé basin, whereas from the middle to the upper Ouémé, a decreasing tendency of heavy rainfall is dominant [8]. In the upper Ouémé basin, a recent work of Attogouinon et al. [9] shows the absence of clear cumulative 
annual rainfall trend over the period 1951-2014. However, when considering the entire Ouémé Basin, $\mathrm{N}^{\prime} \mathrm{Tch}$ a M'Po et al. [10] reported significant declining in the number of heavy and very heavy rainfall days, heavy, and extremely heavy rainfall, consecutive wet days and annual wet-day rainfall total from 1950 to 2014, confirming that trend in rainfall depends on spatial scale as reported by Lawin et al. [11].

Extreme events, like flood, threaten Ouémé Delta area [12]. Climate change impacts on extremes precipitation and rise in sea level, makes coastal Deltas more vulnerable to flood either from ocean or land depending on their positions [13]. Actually, flood is found to be the third most common disaster in coastal regions of West Africa [14]. In 2010, flood disaster in Bénin affected more than 680,000 people, causing the death of 46 persons, with 55 out of 77 municipalities affected, given the overall damages and losses were estimated to more than $46,847,399$ US dollars [15].

Thus, knowledge about hydro-climatologic trends of relatively small wet area, like Deltas, is of great interest, since Deltas are food basket of countries [16]. They are of extremely fertile soils for agriculture and provide easy access to fishery [12]. Even though Deltas were usually subjected to flood as humid area, extreme climatic risks are expected to increase because of nowadays erratic climate variability and changes [17]. Over West Africa, Coupled Model Intercomparaison Project Phase 5 (CMIP5) showed an increase in heavy rainfall by the end of 21st century [18]. Furthermore, regional climate models projected increasing number of extreme rainfall in period of May and July [19]. Observed minimum air temperature increased more rapidly than maximum temperatures [20]. This results in narrow difference between maxima and minima air temperature known as diurnal temperature over most parts of Africa [21]. Near surface temperature has increased by $0.5^{\circ} \mathrm{C}$ or more during the last 50 to 100 years [22]. In West Africa, significant increase in temperature is also shown over the period 1961 to 2000 using indices that were developed by the Expert Team on Climate Change Detection and Indices (ETCCDI) [23].

Trends in other climatic patterns, like sunshine, wind speed, and relative humidity are less explored. However, a lot of works on trend in pan evaporation have been done in diverse climate regions. Results showed that both decreasing and increasing trends that are observed, coexist [24]. Decrease in pan evaporation under a warming climate is known as the pan evaporation paradox because of the contradiction to common expectation. This phenomenon can either be explained by an increase in cloudiness and aerosol concentrations, which results in a decrease in solar radiation received on Earth's surface; or, an increase in terrestrial evaporation that cools down the air over the pan and reduces the evaporation from that pan [25]. However, an increase in pan evaporation is mostly due to an increase in temperature. In Africa, such phenomenon has been less mentioned probably because of limited data according to Oguntunde et al. [25]. These authors showed that pan evaporation, sunshine, and wind speed decrease significantly highly $(p<0.001)$, whereas rainfall, minima temperature, and relative humidity showed insignificant increasing trends in Nigeria over the period 1973-2008. Recently, Djaman et al. [26] showed an increasing trend in pan evaporation at Lomé, Tabligbo, and Sokodé, but a decreasing trend at Atakpamé in Togo over the period 1976-2011.

Pan evaporation is basically used to measure evaporation from free water surface [27]. In Australia, it is shown that surface water losses of around $40 \%$ of their storage are due to evaporation [28]. In West Africa, river discharge is projected to decrease about $50 \%$ by the end of 21 st century $[29,30]$. There is a consensus that climate change impacts are projected to hit more developing countries due to their fragility in terms of adaptation and mitigation capacity [31]. Consequently, primary sectors that are basis of these countries' economy are threatened. Water resources are key element for every development sector, but they are under pressure in Wetlands like Deltas [32]. Moreover, Deltas are likely to face extreme events due to population growth, anthropogenic activities, urbanization, and climate variability $[12,13]$. Therefore, there is a need to investigate pan evaporation change as well as its influencing factors in order to contribute to decision making in surface water management in areas, like Deltas.

Little research has been conducted on pan evaporation trend analysis in Delta around the world due to data unavailability. Moreover, fewer authors look at it relationship with temperature, relative 
humidity, sunshine, and wind speed, as well as those that influence its variation. Nevertheless, it remains a prominent parameter where its trend has to be well known in water resource management, especially in a deltaic region [25]. In Ouémé Delta, little analysis focused on the main climatologic variables trend. Moreover, less discussed are the pan evaporation trend and its explanatory climatic partners. Thus, the present work focuses on change in rainfall and temperature extreme indices, as well as pan evaporation with its influencing factors over the Ouémé Delta. The aims of this work is (1) to analyze trend of extreme rainfall and temperature as well as pan evaporation, sunshine duration, relative humidity, and wind speed at $10 \mathrm{~m}$ altitude (2) to assess the impact of extreme rainfall during high water period and (3) to identify influencing climatic variables of pan evaporation.

\section{Materials and Methods}

\subsection{Study Area}

The study area as shown on Figure 1 is the Ouémé Delta, that is located in the south eastern part of Bénin in West Africa. It is between $6.30^{\circ}$ and $7^{\circ}$ North and between $2.20^{\circ}$ and $2.70^{\circ}$ East. It is $25 \mathrm{~km}$ long in East-West direction and $90 \mathrm{~km}$ width from North to South [33,34]. Ouémé Delta covers the municipalities of Bonou, Adjohoun, Dangbo, Akpro-Missérété, Abomey-Calavi, Aguégué, Porto Novo, Sêmé Kpodji, and Cotonou. With a drainage basin of about $5000 \mathrm{~km}^{2}$, it is a very rich area that offers home to large number of ecological species [33,34]. It is an area well suited not only for agriculture due to nutrients deposit but also for fishery and fluvial transactions. It also gives shelter to a considerable number of human beings who depend on these resources, especially those living on Nokoué Lake as well as those along Ouémé and Sô rivers in the Delta. Nokoué Lake, the biggest in Bénin, is the buffer zone of Ouémé Delta.

Nokoue Lake is positioned between $6.30^{\circ}$ and $6.50^{\circ}$ North and between $2.35^{\circ}$ and $2.50^{\circ}$ East. It is $20 \mathrm{~km}$ long in East-West direction and $11 \mathrm{~km}$ width from North to South [33-35]. It covers $150 \mathrm{~km}^{2}$ in low water and it could increase over $450 \mathrm{~km}^{2}$ in high water [33-35]. It is limited in the West by Abomey-Calavi's plateau, in the East by Porto Novo's Lagoon, in the North by the flood plain of Ouémé and So Rivers, and in the South by Cotonou city. Cotonou and Totchè channels connect it, respectively, to the Atlantic Ocean and to the Porto Novo's Lagoon [35].

Because of its geographical position and the Inter-Tropical Convergence Zone circulation over Bénin, Ouémé Delta is under subequatorial climate with a bimodal rainfall regime [33,34]. This area is characterized by two rainy seasons (April to July and September to November) and two dry seasons (December to March and mid-July to mid-August) [33,34]. Over the period 1960-2016, the annual rainfall amount is between $719 \mathrm{~mm}$ and $2470 \mathrm{~mm}$ at station point. 

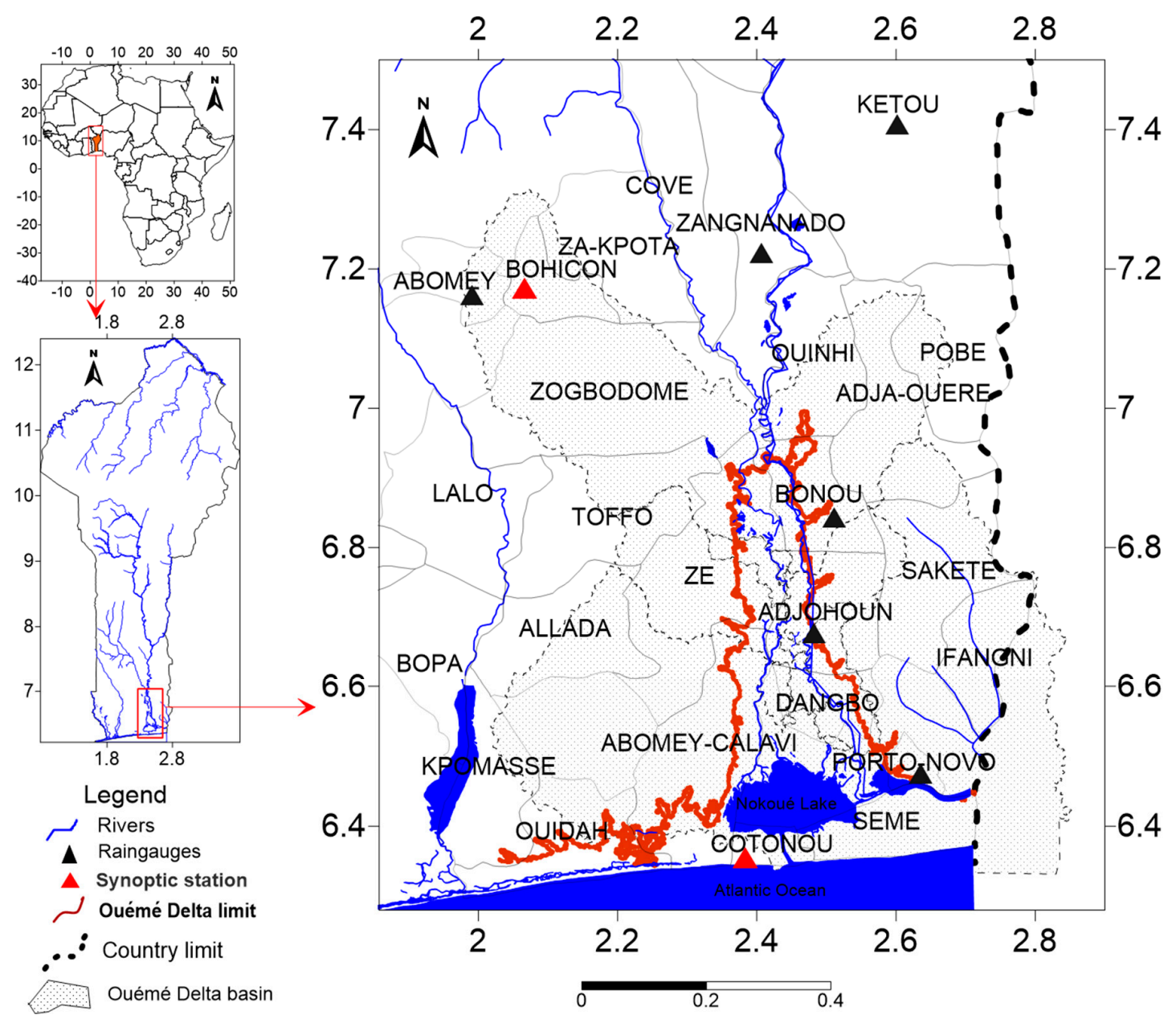

Figure 1. Ouémé Delta geographical position.

\subsection{Data and Quality Control}

Daily data are collected from six (6) rain gauges and two (2) synoptic stations shown by Figure 1 and detailed in Table 1, for the period 1960-2016 from the national meteorological agency. At synoptic stations, daily rainfall (PRCP), daily minimum (TMin), and maximum (TMax) temperature, minimum (Hmin) and maximum (Hmax) relative humidity, as well as daily wind speed (WIND), sunshine duration (SUND) and pan evaporation (EVA) data are collected. Data quality control is processed using RClimpact tool [36]. Unreasonable values are highlighted and removed. These are daily maximum temperature less than daily minimum temperature and daily minimum temperature higher than daily maximum. Outliers in daily maximum and minimum temperature are also identified and removed. Missing data are identified and filled using the double mass cumulus method [37].

Table 1. Summary of available stations over Ouémé Delta with latitude and longitude.

\begin{tabular}{cccc}
\hline Station Name & Acronyms & Longitude (Degree) & Latitude (Degree) \\
\hline Abomey & ABO & 1.98 & 7.18 \\
Adjohoun & ADJ & 2.48 & 6.70 \\
Bohicon & BOH & 2.07 & 7.17 \\
Bonou & BON & 2.50 & 6.93 \\
Cotonou Airport & COT & 2.38 & 6.35 \\
Ketou & KET & 2.61 & 7.36 \\
Porto Novo & POR & 2.62 & 6.48 \\
Zagnanado & ZAG & 2.33 & 7.25 \\
\hline
\end{tabular}




\subsection{Climatic Extremes Indices}

In order to improve early warning system, risk management, and adaptation to both climate change and variability over large space and time scales, the World Meteorological Organization (WMO), through the Commission for Climatology ( $\mathrm{CCl}$ ) Expert Team on Climate Risk and Sector-specific Indices (ET CRSCI), has recently defined, based on rainfall and temperature, 34 extreme indices with nine additional others, to achieve high level of climate knowledge. More detail is given at: http://www.wmo.int/pages/prog/wcp/ccl/opace/opace4/expertteam.php. The analysis of these extreme indices facilitates access to information and products for decision making. In this work, eight temperature based indices and 15 rainfall based indices from WMO core set were computed. A summary of the chosen indices is found in Table 2. Threshold based indices are computed using the baseline period 1981-2010. User-friendly R-based software (ClimPACT) was used to compute the indices.

Table 2. Indices of Expert Team on Climate Risk and Sector-specific Indices (ET CRSCI) core indices where $\mathrm{TN}=$ minimum temperature and $\mathrm{TX}=$ maximum temperature, $\mathrm{p}=$ daily precipitation, and $\mathrm{prcp}$ $=$ annual total precipitation [38].

\begin{tabular}{|c|c|c|c|}
\hline ID & Indicator Name & Definitions & Units \\
\hline TXX & $\operatorname{Max} \mathrm{TX}$ & Monthly maximum value of daily TX & ${ }^{\circ} \mathrm{C}$ \\
\hline TNn & Min TN & Monthly minimum value of daily TN & ${ }^{\circ} \mathrm{C}$ \\
\hline $\mathrm{TNx}$ & Max Tmin & Monthly maximum value of daily min temperature & ${ }^{\circ} \mathrm{C}$ \\
\hline TXn & Min Tmax & Monthly minimum value of daily max temperature & ${ }^{\circ} \mathrm{C}$ \\
\hline WSDI2 & Warm spell duration Indicator & $\begin{array}{l}\text { Annual count of days with at least } 2 \text { consecutive } \\
\text { days when } T X>90 \text { th percentile }\end{array}$ & Days \\
\hline TX95t & Very warm day Threshold & Value of 95th percentile of TX & ${ }^{\circ} \mathrm{C}$ \\
\hline TN95t & Very cold day Threshold & Value of 95th percentile of TN & ${ }^{\circ} \mathrm{C}$ \\
\hline DTR & Diurnal Temperature range & $\begin{array}{l}\text { Monthly mean difference between daily max and } \\
\text { min temperature }\end{array}$ & ${ }^{\circ} \mathrm{C}$ \\
\hline SDII & Simple daily intensity index & $\begin{array}{l}\text { The ratio of annual total precipitation to the number } \\
\text { of wet days (>1 mm) }\end{array}$ & $\mathrm{mm} /$ day \\
\hline $\mathrm{R} 10 \mathrm{~mm}$ & Number of heavy precipitation days & Annual count when precipitation $>10 \mathrm{~mm}$ & days \\
\hline $\mathrm{R} 20 \mathrm{~mm}$ & $\begin{array}{l}\text { Number of very heavy } \\
\text { precipitation days }\end{array}$ & Annual count of days when $P \geq 20 \mathrm{~mm}$ & days \\
\hline CDD & Consecutive dry Days & $\begin{array}{l}\text { Maximum number of consecutive days with } \\
\qquad \mathrm{P}<1 \mathrm{~mm}\end{array}$ & days \\
\hline CWD & Consecutive wet days & $\begin{array}{l}\text { Maximum number of consecutive days when } \\
\text { precipitation } \geq 1 \mathrm{~mm}\end{array}$ & days \\
\hline R95pTOT & Contribution from very wet days & $\begin{array}{l}\text { Annual percentage of RR } \\
>\text { 95th percentile/PRCPTOT }\end{array}$ & $\%$ \\
\hline R99pTOT & $\begin{array}{l}\text { Contribution from extremely } \\
\text { wet days }\end{array}$ & Annual percentage of $\mathrm{P}>$ 99th percentile/PRCPTOT & $\%$ \\
\hline R95p & Very wet days & $\begin{array}{l}\text { Annual total precipitation from days }>95 \text { th } \\
\text { percentile }\end{array}$ & $\mathrm{mm}$ \\
\hline PRCPTOT & Annual total wet-day precipitation & PRCP from wet days $(\mathrm{P} \geq 1 \mathrm{~mm})$ & $\mathrm{mm}$ \\
\hline R99p & Extremely wet days & $\begin{array}{l}\text { Annual total precipitation from days }>99 \text { th } \\
\text { percentile }\end{array}$ & $\mathrm{mm}$ \\
\hline RX1day & Max 1-day precipitation amount & Monthly maximum 1-day precipitation & $\mathrm{mm}$ \\
\hline RX2day & Max 2-day precipitation amount & Monthly maximum consecutive 2-day precipitation & $\mathrm{mm}$ \\
\hline RX3day & Max 3-days precipitation amount & Monthly maximum consecutive 3-days precipitation & $\mathrm{mm}$ \\
\hline RX5day & Max 5-day precipitation amount & Monthly maximum consecutive 5-day precipitation & $\mathrm{mm}$ \\
\hline RX10day & Max 10-days precipitation amount & Monthly maximum consecutive 10 days precipitation & $\mathrm{mm}$ \\
\hline
\end{tabular}

\subsection{Trends Analysis}

Trend analysis is conducted at annual scale on each of the eight temperature based indices as well as the 15 rainfall based indices. In addition, trend in maximum consecutive 1, 2, 3, 5, and 10 days precipitation are computed at a monthly scale within the high water period in Ouémé Delta. We focused more on heavy rainfall during the high water period to assess its impacts on flood events. High water in the Delta area occurs essentially from September to November. This period represents 
the second rainy season in that area. Trends are detected using Mann-Kendall, as shown by Mann [39] and Kendall [40], and a prewhitened Mann-Kendall test at the 0.05 confidence level by Brien [41], as shown on Figure 2.

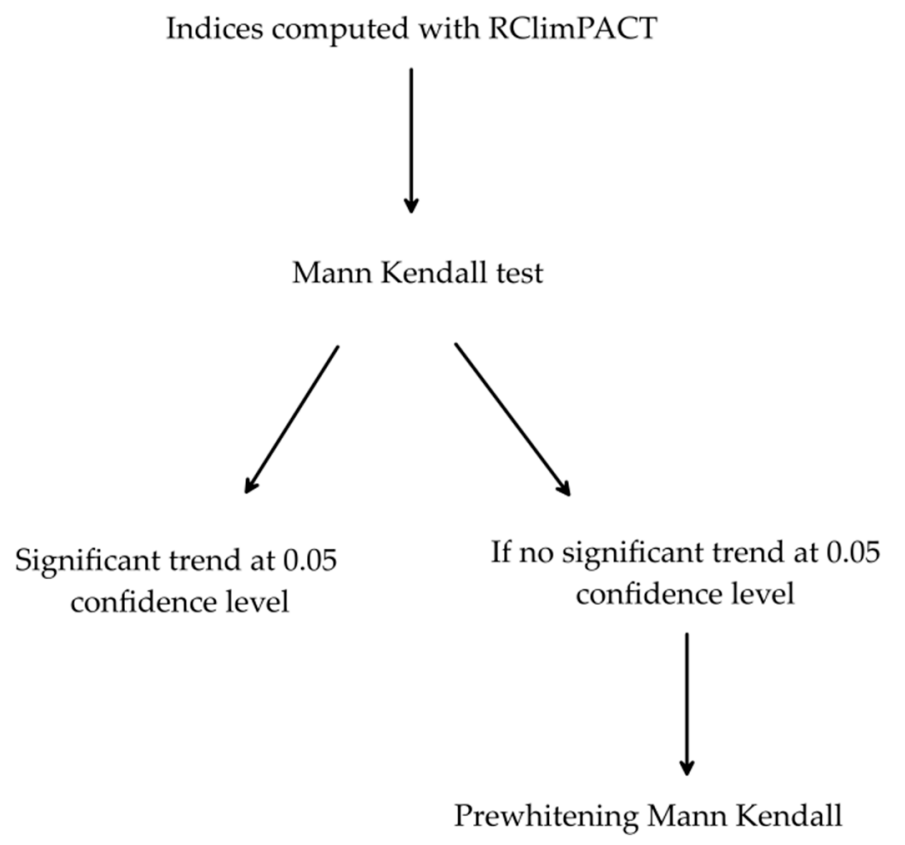

Figure 2. Trend analysis process sketch.

\subsubsection{Mann-Kendall Test}

The well-known Mann-Kendall test is a non-parametric test that is commonly employed for monotonic trend analysis in series of environmental data, climate data, or hydrological data. This test assesses the existence of a monotonic upward or downward trend of the variable of interest over time. A monotonic upward (downward) trend of a variable means its consistent increase (decrease) through time; however, the trend may or may not be linear. Thus, the Mann-Kendall test is preferably used instead of a parametric linear regression analysis, to enable the detection of a non-linear trend. This test does not require data to be normally distributed. Furthermore, it is not sensitive to abrupt breaks due to non homogeneous time series [42]. However, Thiel Sen's slope method that uses a linear model to estimate the slope of the trend and the variance of the residuals should be constant in time [43].

The null hypothesis of the Mann-Kendall test, H0, is that data come from a population with independent realizations with identical distribution. The alternative hypothesis, $\mathrm{H} 1$, is that data follows a monotonic trend. In this work, the trend was detected at the 0.05 confidence level using Mann-Kendall test package in $\mathrm{R}$ [41], where Tau is the correlation rank strength, Sen slope the magnitude, and $p$ value the probability.

\subsubsection{Prewhitened Mann-Kendall Test}

In the case that the Mann-Kendall test detects no trend, a prewhitening Mann-Kendall test was used to detect a probable trend covered by internal serial correlation. In fact, prewhitening is processed to remove serial correlation in the data set following Yue et al. [44]. The presence of serial correlation in hydro meteorological time series often makes the detection of fake deterministic gradual or abrupt changes with tests such as Mann-Kendall (MK) [45]. Though, Mann Kendal test has shown a strong performance in trend detection, there are some limitation due to its own null hypothesis based on the assumption that data are independently and identically distributed [46]. Serial correlation increases the variance of the test statistic. As consequence, it increases the rejection rate of the null hypothesis. 
Then, the prewhitening procedure decreases the inflation of the variance of the test statistic due to serial correlation and reduces the rate of rejection below the rate before prewhitening [47].

As result, it is important to prewritten when there is no trend. In fact, Yue et al. [48] stated that prewhitening is not suitable for eliminating the effect of serial correlation on the Mann-Kendall test when trend exists in a time series, because it removes a portion (equal to the lag-one autocorrelation coefficient) of trend and hence reduces the probability of rejecting the null hypothesis when it is false.

\subsubsection{Relationship between Pan Evaporation and Other Meteorological Patterns in Ouémé Delta}

In order to determine the main explanatory variables of pan evaporation, partial correlation and stepwise regression is used. Partial correlation is used in the case of one variable being partially correlated with some other independent ones. Thus, each partial correlation coefficient obtained represents the contribution of each independent variable to the dependent one. In fact, it is shown that pan evaporation is governed by three conditions: thermal, turbulent, and vapor conditions, each of which is influenced by group of pan evaporation explanatory variables, as shown by Liu et al. [49]. In addition, stepwise regression is used to quantify the relative weight of each variable to the dependent [24]. Thus, stepwise regression is used to further partial the correlation results. In this study, the correlation coefficient is determined daily between pan evaporation and each of the nine (9) following variables: Rainfall, minimum and maximum temperature, mean temperature, minimum and maximum relative humidity, mean relative humidity, wind speed, and sunshine. Stepwise regression is a variable selection procedure for selecting the fewest most useful independent variables that are believed to be the most essential in the final prediction equation, which is as follows:

$$
Y=\beta_{0}+\beta_{1} X_{1}+\beta_{2} X_{2}+\ldots+\beta_{n} X_{n}
$$

where $Y$ is the dependent variable, $X_{1, \ldots, n}$ the $n$ independent explanatory variables, $\beta_{0}$ is the $\mathrm{y}$-intercept, and $\beta_{1, \ldots, n}$ are the estimate of model parameters relatively to each dependent variable. The selection consists in a series of step to find the most significant independent variable to be included in the final regression model based on a set criterion, which is here the t-statistic. At each step of the regression, the independent variable retained is the one with the highest absolute $\mathrm{t}$-value with $p$ value being considered at the $\alpha$ confidence level.

\section{Results}

Rainfall and temperature based indices, as well as maximum, minimum and mean of relative humidity, wind speed pan evaporation, and sunshine, are computed at the annual scale. In addition, maximum Xday precipitation amount indices are computed at monthly scale to further understand extreme events in the Delta area. Moreover, monthly sunshine and pan evaporation trend is detected to assess their impact on water resources.

\subsection{Rainfall Indices}

The trend analysis results of rainfall in the Ouémé Delta are summarized below with numbers in bold indicating significant trend at the 0.05 confidence level. Results show at an annual scale that the prewhitening process did not add value to the trend analysis in the Ouémé Delta.

\subsubsection{Annual Based Rainfall Trends Analysis}

Results of rainfall intensity indices such as annual precipitation amount (PRCPTOT), number of heavy and very heavy precipitation days (R10mm, R20mm) as well as consecutive wet days (CWD), with significant trend, at least in one station are shown in Table 3. 
Table 3. Significant trend results of annual rainfall intensity indices.

\begin{tabular}{|c|c|c|c|c|c|c|c|c|c|c|c|c|}
\hline \multirow{2}{*}{ Stations } & \multicolumn{3}{|c|}{ PRCPTOT } & \multicolumn{3}{|c|}{$\mathrm{R} 10 \mathrm{~mm}$} & \multicolumn{3}{|c|}{$\mathrm{R} 20 \mathrm{~mm}$} & \multicolumn{3}{|c|}{ CWD } \\
\hline & Tau & Sen Slope & $p$ Value & Tau & Sen Slope & $p$ Value & Tau & Sen Slope & $p$ Value & Tau & Sen Slope & $p$ Value \\
\hline ABOMEY & -0.1 & -1.8 & 0.6 & -0.1 & -0.1 & 0.4 & -0.1 & 0.0 & 0.6 & -0.218 & 0 & 0.048 \\
\hline ADJOHOUN & 0.3 & 8.4 & 0.0 & 0.3 & 0.3 & 0.0 & 0.3 & 0.2 & 0.0 & 0.074 & 0.001 & 0.484 \\
\hline BOHICON & 0.1 & 1.8 & 0.5 & 0.0 & 0.0 & 1.0 & 0.0 & 0.0 & 0.7 & -0.26 & -0.022 & 0.009 \\
\hline BONOU & 0.3 & 13.3 & 0.0 & 0.4 & 0.7 & 0.0 & 0.4 & 0.5 & 0.0 & -0.061 & -0.012 & 0.63 \\
\hline COTONOU AIRPORT & 0.0 & 0.0 & 1.0 & 0.0 & 0.0 & 0.6 & 0.0 & 0.0 & 0.8 & -0.201 & -0.034 & 0.037 \\
\hline KETOU & 0.1 & 2.0 & 0.5 & 0.0 & 0.0 & 0.7 & 0.1 & 0.0 & 0.6 & 0.057 & 0 & 0.619 \\
\hline PORTO NOVO & -0.2 & -6.7 & 0.1 & -0.3 & -0.3 & 0.0 & -0.1 & -0.1 & 0.4 & -0.448 & -0.083 & 0 \\
\hline ZAGNANADO & 0.3 & 10.3 & 0.0 & 0.3 & 0.4 & 0.0 & 0.3 & 0.2 & 0.0 & 0.141 & 0.028 & 0.237 \\
\hline
\end{tabular}


Rainfall intensity indices trend results showed in Table 3 are plotted on Figure 3.
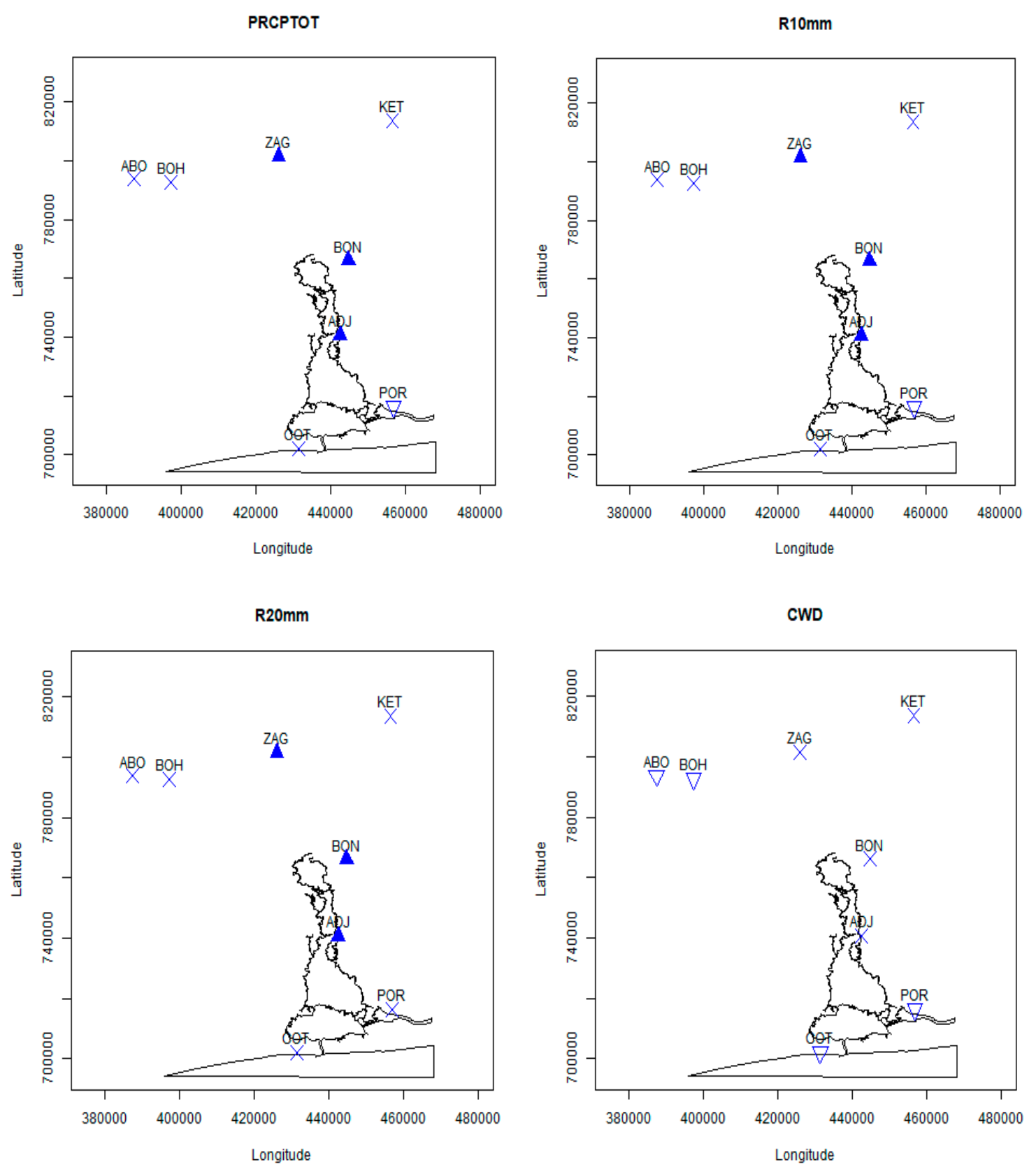

A Significant increasing trend

$\nabla$ Significant decreasing trend

No significant trend

Figure 3. Plot of Annual total precipitation (PRCPTOT), R10mm, R20mm trend, and consecutive wet day (CWD) over Ouémé Delta.

Results of rainfall frequency indices like Simple daily intensity index (SDII), contribution from very wet days (R95pTOT) and contribution from extremely wet days (R99pTOT), with significant trend, at least in one station are shown in Table 4. 
Table 4. Significant trend results of annual rainfall frequency indices.

\begin{tabular}{ccccccccccc}
\hline \multirow{2}{*}{ Stations } & \multicolumn{3}{c}{ SDII } & \multicolumn{3}{c}{ R95pTOT } & \multicolumn{3}{c}{ R99pTOT } \\
\cline { 2 - 10 } & Tau & Sen Slope & $p$ Palue & Tau & Sen Slope & $p$ Value & Tau & Sen Slope & $p$ Value \\
\hline ABOMEY & 0.2 & 0.0 & 0.1 & 0.123 & 0.001 & 0.484 & 0.029 & 0 & 0.889 \\
ADJOHOUN & $\mathbf{0 . 2}$ & $\mathbf{0 . 1}$ & $\mathbf{0 . 0}$ & -0.305 & -0.005 & 0.064 & $-\mathbf{0 . 3 7 1}$ & $-\mathbf{0 . 0 0 3}$ & $\mathbf{0 . 0 2}$ \\
BOHICON & $\mathbf{0 . 2}$ & $\mathbf{0 . 0}$ & $\mathbf{0 . 0}$ & 0.163 & 0.002 & 0.212 & 0.076 & 0.001 & 0.568 \\
BONOU & $\mathbf{0 . 6}$ & $\mathbf{0 . 3}$ & $\mathbf{0 . 0}$ & -0.278 & -0.011 & 0.348 & 0.111 & 0.005 & 0.754 \\
COTONOU & 0.0 & 0.0 & 0.6 & 0.261 & 0.004 & 0.078 & 0.145 & 0.002 & 0.333 \\
AIRPORT & 0.0 & 0.0 & 0.9 & $-\mathbf{0 . 3 8 9}$ & $-\mathbf{0 . 0 0 5}$ & $\mathbf{0 . 0 1 8}$ & -0.041 & -0.001 & 0.834 \\
KETOU & $\mathbf{0 . 3}$ & $\mathbf{0 . 1}$ & $\mathbf{0 . 0}$ & $\mathbf{0 . 3 2 6}$ & $\mathbf{0 . 0 0 6}$ & $\mathbf{0 . 0 4 8}$ & -0.24 & -0.003 & 0.162 \\
PORTO NOVO & $\mathbf{0 . 3}$ & 0.2 & 0.121 & 0.004 & 0.631 & 0.152 & 0.001 & 0.537 \\
ZAGNANADO & 0.2 & 0.1 & $\mathbf{0}$ & & & & & & &
\end{tabular}

Rainfall frequency indices trend results showed in Table 4 are plotted on Figure 4.
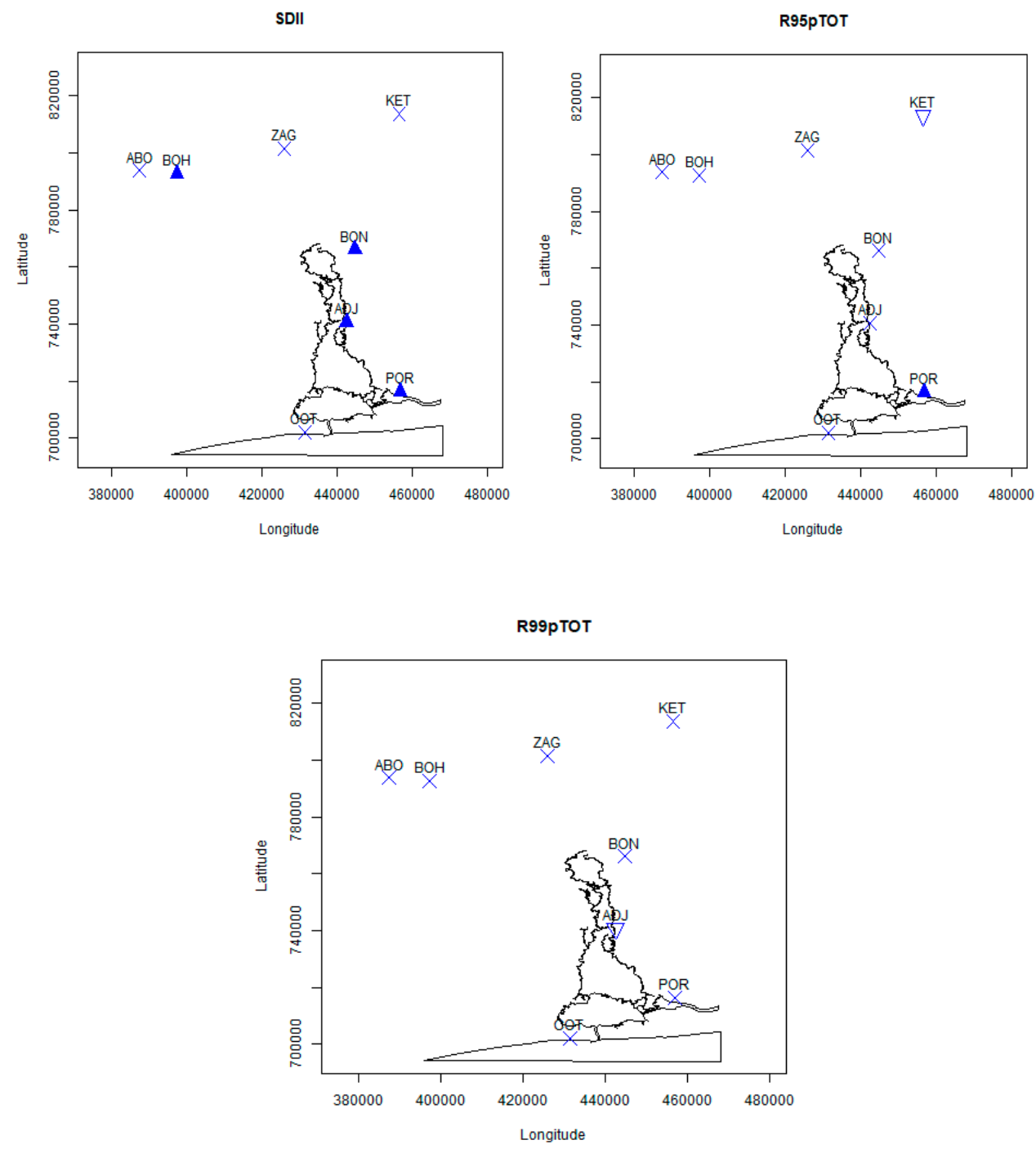

A Significant increasing trend

$\nabla$ Significant decreasing trend

No significant trend

Figure 4. Plot of Simple daily intensity index (SDII), very wet day (R95pTOT), and extremely wet days (R99pTOT) trend over Ouémé Delta.

Rainfall indices with no significant trend are summarized in Tables 5 and 6. 
Table 5. Annual rainfall intensity indices with no trend.

\begin{tabular}{|c|c|c|c|c|c|c|c|c|c|c|c|c|}
\hline \multirow{2}{*}{ Stations } & \multicolumn{3}{|c|}{ RX1day } & \multicolumn{3}{|c|}{ RX2day } & \multicolumn{3}{|c|}{ RX3day } & \multicolumn{3}{|c|}{ RX5day } \\
\hline & Tau & Sen Slope & $p$ Value & Tau & Sen Slope & $p$ Value & Tau & Sen Slope & $p$ Value & Tau & Sen Slope & $p$ Value \\
\hline ABOMEY & 0.1 & 0.1 & 0.6 & 0.1 & 0.2 & 0.4 & 0.1 & 0.3 & 0.3 & 0.0 & 0.1 & 0.8 \\
\hline ADJOHOUN & 0.1 & 0.1 & 0.6 & 0.0 & 0.0 & 1.0 & 0.1 & 0.3 & 0.4 & 0.1 & 0.2 & 0.6 \\
\hline BOHICON & 0.1 & 0.1 & 0.4 & 0.2 & 0.4 & 0.1 & 0.1 & 0.2 & 0.3 & 0.0 & 0.1 & 0.7 \\
\hline BONOU & 0.0 & 0.0 & 1.0 & 0.0 & -0.1 & 0.8 & 0.0 & -0.2 & 0.7 & 0.1 & 0.4 & 0.6 \\
\hline COTONOU AIRPORT & -0.1 & -0.4 & 0.3 & -0.1 & -0.4 & 0.2 & -0.1 & -0.5 & 0.3 & -0.1 & -0.8 & 0.2 \\
\hline KETOU & 0.0 & 0.0 & 1.0 & 0.1 & 0.3 & 0.4 & 0.1 & 0.2 & 0.5 & 0.1 & 0.5 & 0.2 \\
\hline PORTO NOVO & -0.1 & -0.2 & 0.4 & -0.1 & -0.3 & 0.4 & 0.0 & -0.3 & 0.7 & -0.1 & -0.7 & 0.3 \\
\hline ZAGNANADO & 0.2 & 0.4 & 0.2 & 0.1 & 0.5 & 0.3 & 0.1 & 0.3 & 0.5 & 0.0 & 0.1 & 0.8 \\
\hline
\end{tabular}

Table 6. Annual consecutive dry day (CDD), very wet day (R95p), and extremely wet day (R99p) indices trend with no trend.

\begin{tabular}{|c|c|c|c|c|c|c|c|c|c|c|c|c|}
\hline \multirow{2}{*}{ Stations } & \multicolumn{3}{|c|}{ RX10day } & \multicolumn{3}{|c|}{ R95p } & \multicolumn{3}{|c|}{ R99p } & \multicolumn{3}{|c|}{ CDD } \\
\hline & Tau & Sen Slope & $p$ Value & Tau & Sen Slope & $p$ Value & Tau & Sen Slope & $p$ Value & Tau & Sen Slope & $p$ Value \\
\hline ABOMEY & -0.1 & -0.2 & 0.6 & 0.1 & 1.3 & 0.3 & 0.1 & 0 & 0.6 & 0.014 & 0.043 & 0.895 \\
\hline ADJOHOUN & 0.1 & 0.3 & 0.5 & 0 & 0.6 & 0.7 & 0 & 0 & 0.9 & -0.11 & -0.265 & 0.298 \\
\hline BOHICON & 0.1 & 0.3 & 0.4 & 0.1 & 1.3 & 0.2 & 0 & 0 & 0.7 & 0.083 & 0.229 & 0.369 \\
\hline BONOU & 0.1 & 1 & 0.4 & 0 & -0.5 & 0.8 & 0 & 0 & 0.7 & 0.123 & 0.564 & 0.321 \\
\hline COTONOU AIRPORT & -0.1 & -0.7 & 0.2 & -0.1 & -0.9 & 0.5 & -0.1 & 0 & 0.5 & 0.081 & 0.141 & 0.381 \\
\hline KETOU & 0 & 0.1 & 0.9 & 0 & 0 & 1 & 0 & 0 & 0.7 & 0.198 & 0.811 & 0.077 \\
\hline PORTO NOVO & -0.1 & -0.5 & 0.5 & -0.1 & -1.4 & 0.5 & -0.1 & 0 & 0.3 & 0.073 & 0.179 & 0.474 \\
\hline ZAGNANADO & 0.1 & 0.4 & 0.4 & 0.1 & 2.4 & 0.4 & 0.1 & 0 & 0.4 & 0.146 & 0.668 & 0.222 \\
\hline
\end{tabular}


At the annual scale, intensity indices, such as maximum consecutive 10-day precipitation amount (RX10day), annual total precipitation from very wet days (R95p), and annual total precipitation from extremely wet days (R99p) show no significant trend over the entire study area (Table 6). Similarly, no significant trend is detected for maximum one-day precipitation amount (RX1day) and maximum consecutive two-day precipitation amount (RX2day) over the entire study area as shown in Table 5. In addition, maximum consecutive three-day precipitation amount (RX3day) and maximum consecutive five-day precipitation amount (RX5day) also show no significant trend over the entire study area, as shown in Table 5. Annual total precipitation (PRCPTOT) shows a significant decreasing trend of about $6.7 \mathrm{~mm} /$ year at the southeast station Porto Novo, whereas from North to South Zagnanado, Bonou, and Adjohoun show significant increasing trends (Figure 3), respectively, with slopes of 10.3, 13.3, and $8.4 \mathrm{~mm} /$ year.

Consecutive dry day (CDD) shows no significant trend over the entire area of study, as shown on Table 6. However, consecutive wet day (CWD) is significantly slightly decreasing at Abomey, Bohicon, Porto Novo, and Cotonou Airport, as shown on Figure 3. The number of heavy and very heavy precipitation days (R10mm, R20mm) increases at Zagnanado, Bonou, and Adjohoun (Figure 3). However, the number of heavy precipitation days decreases at Porto-Novo. Contribution from very wet days (R95pTOT) shows an increasing trend only at Porto Novo (Figure 4), whereas contribution from extremely wet days (R99pTOT) decreases at Adjohoun (Figure 4). Simple daily intensity index (SDII) increases at Adjohoun, Bonou, and Porto Novo (Figure 4), respectively, with slope of 0.1, 0.3 and 0.1. Increase in annual total precipitation is due to more frequent heavy and very heavy rainfall event. This intensification in the frequency of extreme rainfall events will result in high peak flow and then more damageable flood events in the high water period. Moreover, the most impacted areas is going to be those closer to Ouémé Delta, since significant trends are detected at the closest stations.

\subsubsection{Trend Analysis in Monthly Maximum Precipitation}

In order to detect change in intense precipitation at short time scale, the monthly trend has been computed on maximum 1, 2, 3, 5, and 10 days precipitation at all stations. Results are shown below with numbers in bold showing significant trend at the 0.05 confidence level. Maximum 1 and 2 days precipitation results are shown in Table 7.

Maximum 3 and 5 days precipitation results are shown in Table 8.

Maximum 10 days precipitation results are shown in Table 9.

At the monthly scale, maximum consecutive 1, 2, and 3-day precipitation amount showed significant increasing trend in Adjohoun in February. In addition, maximum consecutive 10-day precipitation amount significantly decreased at Porto Novo in March. Maximum one-day precipitation increased significantly at Cotonou Airport in September. In October, maximum consecutive 10 days precipitation increased significantly at Cotonou Airport and Porto Novo. The trends listed above were detected only after prewhitening.

In April, Bonou showed a significant decreasing trend for maximum consecutive 2, 3, and 5-day precipitation amount. As consequence, water stress is going to impact on garden products yield in Bonou. In addition, maximum consecutive 5-day precipitation in Cotonou Airport decreased significantly for the same month. In contrary, Zagnanado showed significant increasing trend for maximum consecutive 2 and 3-day precipitation, whereas Adjohoun increased significantly only for maximum consecutive 3-day precipitation. In July, Bohicon and Zagnanado maximum 3 and 5-day increased significantly, while maximum consecutive 10-day significantly decreased at Porto Novo. It seems to be the most watered area during the first rainy season, which is from April to July. In August, maximum consecutive 2, 3, 5, and 10-day significantly increased only at Zagnanado. Thus, Agriculture at Zagnanado suffers less from water stress, but it is susceptible to flood event. 
Table 7. Monthly trend analysis of one-day precipitation amount (RX1day) and two-day precipitation amount (RX2day) during high water.

\begin{tabular}{|c|c|c|c|c|c|c|c|c|c|c|c|c|c|c|c|c|c|c|}
\hline \multirow{3}{*}{ Stations } & \multicolumn{9}{|c|}{ RX1day } & \multicolumn{9}{|c|}{ RX2day } \\
\hline & \multicolumn{3}{|c|}{ SEP } & \multicolumn{3}{|c|}{ OCT } & \multicolumn{3}{|c|}{ NOV } & \multicolumn{3}{|c|}{ SEP } & \multicolumn{3}{|c|}{ OCT } & \multicolumn{3}{|c|}{ NOV } \\
\hline & Tau & $\begin{array}{c}\text { Sen } \\
\text { Slope }\end{array}$ & $p$ Value & Tau & $\begin{array}{c}\text { Sen } \\
\text { Slope }\end{array}$ & $p$ Value & Tau & $\begin{array}{c}\text { Sen } \\
\text { Slope }\end{array}$ & $p$ Value & Tau & $\begin{array}{c}\text { Sen } \\
\text { Slope }\end{array}$ & $p$ Value & Tau & $\begin{array}{c}\text { Sen } \\
\text { Slope }\end{array}$ & $p$ Value & Tau & $\begin{array}{c}\text { Sen } \\
\text { Slope }\end{array}$ & $p$ Value \\
\hline ABOMEY & 0.0 & 0.1 & 0.7 & -0.1 & -0.1 & 0.6 & 0.0 & 0.0 & 0.9 & 0.0 & 0.1 & 0.8 & -0.1 & -0.2 & 0.4 & 0.0 & 0.0 & 0.9 \\
\hline ADJOHOUN & 0.0 & 0.0 & 0.9 & 0.2 & 0.2 & 0.1 & 0.3 & 0.5 & 0.0 & 0.0 & 0.0 & 1.0 & 0.3 & 0.5 & 0.0 & 0.4 & 0.6 & 0.0 \\
\hline BOHICON & 0.1 & 0.2 & 0.2 & 0.1 & 0.2 & 0.3 & 0.1 & 0.1 & 0.4 & 0.2 & 0.3 & 0.1 & 0.1 & 0.1 & 0.5 & 0.2 & 0.2 & 0.1 \\
\hline BONOU & 0.1 & 0.2 & 0.4 & 0.3 & 0.4 & 0.0 & 0.0 & 0.0 & 0.9 & 0.1 & 0.2 & 0.6 & 0.3 & 0.5 & 0.0 & 0.1 & 0.2 & 0.3 \\
\hline COTONOU AIRPORT & 0.2 & 0.4 & 0.0 & 0.1 & 0.1 & 0.4 & 0.0 & 0.0 & 0.8 & 0.2 & 0.4 & 0.0 & 0.0 & 0.1 & 0.8 & 0.0 & 0.0 & 0.9 \\
\hline KETOU & 0.1 & 0.1 & 0.6 & 0.2 & 0.3 & 0.0 & 0.1 & 0.1 & 0.3 & 0.0 & 0.1 & 0.8 & 0.2 & 0.4 & 0.0 & 0.1 & 0.1 & 0.3 \\
\hline PORTO NOVO & 0.2 & 0.5 & 0.1 & 0.0 & 0.1 & 0.8 & -0.3 & -0.4 & 0.0 & 0.1 & 0.5 & 0.1 & 0.0 & 0.1 & 0.8 & -0.3 & -0.4 & 0.0 \\
\hline ZAGNANADO & 0.1 & 0.3 & 0.5 & 0.1 & 0.3 & 0.3 & 0.0 & 0.0 & 0.9 & 0.1 & 0.5 & 0.2 & 0.1 & 0.2 & 0.5 & 0.0 & 0.0 & 1.0 \\
\hline
\end{tabular}

Table 8. Monthly trend analysis of three-day precipitation amount (RX3day) and five-day precipitation amount (RX5day) during high water.

\begin{tabular}{|c|c|c|c|c|c|c|c|c|c|c|c|c|c|c|c|c|c|c|}
\hline \multirow{3}{*}{ Stations } & \multicolumn{9}{|c|}{ RX3day } & \multicolumn{9}{|c|}{ RX5day } \\
\hline & \multicolumn{3}{|c|}{ SEP } & \multicolumn{3}{|c|}{ OCT } & \multicolumn{3}{|c|}{ NOV } & \multicolumn{3}{|c|}{ SEP } & \multicolumn{3}{|c|}{ OCT } & \multicolumn{3}{|c|}{ NOV } \\
\hline & Tau & $\begin{array}{l}\text { Sen } \\
\text { Slope }\end{array}$ & $p$ Value & Tau & $\begin{array}{l}\text { Sen } \\
\text { Slope }\end{array}$ & $p$ Value & Tau & $\begin{array}{l}\text { Sen } \\
\text { Slope }\end{array}$ & $p$ Value & Tau & $\begin{array}{l}\text { Sen } \\
\text { Slope }\end{array}$ & $p$ Value & Tau & $\begin{array}{l}\text { Sen } \\
\text { Slope }\end{array}$ & $p$ Value & Tau & $\begin{array}{l}\text { Sen } \\
\text { Slope }\end{array}$ & $p$ Value \\
\hline ABOMEY & 0 & 0.1 & 0.7 & -0.1 & -0.2 & 0.3 & 0.1 & 0.1 & 0.6 & 0.1 & 0.3 & 0.5 & 0 & 0 & 0.9 & 0 & 0 & 0.9 \\
\hline ADJOHOUN & 0 & 0.1 & 0.7 & 0.3 & 0.6 & 0 & 0.3 & 0.6 & 0 & 0.1 & 0.4 & 0.5 & 0.4 & 1 & 0 & 0.4 & 0.9 & 0 \\
\hline BOHICON & 0.2 & 0.4 & 0.1 & 0.1 & 0.2 & 0.5 & 0.1 & 0.2 & 0.1 & 0.2 & 0.6 & 0 & 0.1 & 0.3 & 0.3 & 0.1 & 0.2 & 0.2 \\
\hline BONOU & 0.1 & 0.3 & 0.3 & 0.3 & 0.6 & 0 & 0.1 & 0.2 & 0.3 & 0.1 & 0.3 & 0.3 & 0.3 & 0.9 & 0 & 0.2 & 0.5 & 0.1 \\
\hline COTONOU AIRPORT & 0.2 & 0.5 & 0 & 0 & 0.1 & 0.8 & 0 & 0 & 0.9 & 0.2 & 0.6 & 0 & 0.1 & 0.4 & 0.2 & 0 & 0 & 0.9 \\
\hline KETOU & 0.1 & 0.2 & 0.4 & 0.1 & 0.3 & 0.3 & 0.1 & 0.2 & 0.2 & 0.1 & 0.3 & 0.4 & 0.2 & 0.6 & 0 & 0.2 & 0.3 & 0.2 \\
\hline PORTO NOVO & 0.2 & 0.7 & 0.1 & 0.1 & 0.2 & 0.3 & -0.3 & -0.4 & 0 & 0.1 & 0.8 & 0.1 & 0.2 & 0.5 & 0.1 & -0.2 & -0.5 & 0 \\
\hline ZAGNANADO & 0.2 & 0.8 & 0 & 0.1 & 0.3 & 0.4 & 0 & 0 & 1 & 0.3 & 1 & $\mathbf{0}$ & 0.2 & 0.7 & 0 & 0 & 0 & 0.8 \\
\hline
\end{tabular}


Table 9. Monthly trend analysis of ten-day precipitation amount (RX10day) during high water.

\begin{tabular}{cccccccccc}
\hline & \multicolumn{3}{c}{ SEP } & \multicolumn{3}{c}{ OCT } & \multicolumn{2}{c}{ NOV } \\
\cline { 2 - 10 } Stations & Tau & Sen Slope & $p$ Value & Tau & Sen Slope & $p$ Value & Tau & Sen Slope & $p$ Value \\
\hline ABOMEY & 0.1 & 0.5 & 0.3 & 0 & 0 & 0.9 & 0 & 0 & 0.9 \\
ADJOHOUN & 0.1 & 0.6 & 0.3 & $\mathbf{0 . 3}$ & $\mathbf{1 . 4}$ & $\mathbf{0}$ & $\mathbf{0 . 4}$ & $\mathbf{1 . 4}$ & $\mathbf{0}$ \\
BOHICON & $\mathbf{0 . 2}$ & $\mathbf{0 . 8}$ & $\mathbf{0}$ & 0.1 & 0.4 & 0.2 & 0.1 & 0.2 & 0.5 \\
BONOU & $\mathbf{0 . 2}$ & $\mathbf{1 . 2}$ & $\mathbf{0}$ & $\mathbf{0 . 3}$ & $\mathbf{1 . 1}$ & $\mathbf{0}$ & 0 & 0.1 & 0.8 \\
COTONOU & $\mathbf{0 . 2}$ & $\mathbf{0 . 8}$ & $\mathbf{0}$ & $\mathbf{0 . 2}$ & $\mathbf{0 . 7}$ & $\mathbf{0 . 1}$ & 0 & 0 & 0.9 \\
AIRPORT & 0.1 & 0.6 & 0.3 & 0.2 & 0.7 & 0.1 & 0.2 & 0.5 & 0.1 \\
KETOU & 0.1 & 0.8 & 0.2 & $\mathbf{0 . 2}$ & $\mathbf{0 . 7}$ & $\mathbf{0 . 1}$ & $-\mathbf{0 . 3}$ & $\mathbf{- 0 . 9}$ & $\mathbf{0}$ \\
PORTO NOVO & 0.1 & 0.1 & 0.8 \\
ZAGNANADO & $\mathbf{0 . 3}$ & $\mathbf{1 . 8}$ & $\mathbf{0}$ & 0.2 & 0.7 & 0.2 & 0 & 0.1 & \\
\hline
\end{tabular}

In Ouémé Delta, high water period runs from September to November. In September, maximum consecutive 1, 2, 3, 5, and 10-days precipitation exhibits a significant increasing trend Cotonou Airport. Only Maximum consecutive 3, 5, and 10-days precipitation increased at Zagnanado. Maximum consecutive 5 and 10-days precipitation at Bohicon as well as maximum consecutive 10 days precipitation increased at Bonou. In October, maximum 1, 2, 3, 5, and 10-day precipitation increased significantly at Bonou. Maximum consecutive 1, 2, and 5-days precipitation increased significantly at Kétou. Maximum consecutive 2, 3 and 5 days precipitation increased significantly at Adjohoun. Only maximum consecutive five days precipitation increased significantly at Zagnanado. In November, maximum consecutive 1, 2, 3, 5, and 10-days precipitation increased significantly only at Adjohoun, but they all decreased significantly at Porto Novo.

In general, most of the stations showed increasing trend at least for one of the maximum 1, 2, 3, 5, and 10-days precipitation amount in the months of September, October, and November, except Porto Novo, which showed a decreasing trend for all of these indices in November.

With these findings, more attention and effort have to be made in early warning system development in the Delta area to decrease damages and losses in term of human resources as well as agricultural products.

\subsection{Trend Analysis in Temperature, Relative Humidity, Pan Evaporation, Sunshine Duration and Wind Speed at $10 \mathrm{~m}$ Altitude}

The trend of each climatic variable, such as temperature, relative humidity, and wind speed in this section was computed at the annual scale taking into account the mean, minimum, and maximum at two synoptic stations in the Delta area. Sunshine and pan evaporation were computed at annual as well as monthly scale. Table 10 shows results of temperature based indices trend.

Table 11 shows results of minimum, maximum and mean value at annual scale for maximal relative humidity as well as wind speed at $10 \mathrm{~m}$ altitude.

Monthly and annual significant trend results for sunshine and pan evaporation are shown in Table 12.

At annual scale, all temperature based indices considered show a significant increasing trend at the two synoptic stations except the diurnal temperature (DTR), very warm day (TX95t), and very cold day (TN95t) temperature thresholds that decreased, respectively, about $0.012{ }^{\circ} \mathrm{C}, 0.008^{\circ} \mathrm{C}$, and $0.006{ }^{\circ} \mathrm{C}$ in averages, as shown in Table 10. In fact, annual minimum (TXn) and annual maximum (TXx) of daily maximal temperature as well as annual minimum $(\mathrm{TNn})$ and annual maximum $(\mathrm{TNx})$ of daily minimal temperature showed significant increasing trends, respectively, of $0.032{ }^{\circ} \mathrm{C}, 0.018{ }^{\circ} \mathrm{C}, 0.027^{\circ} \mathrm{C}$, and $0.025^{\circ} \mathrm{C}$ in averages, as shown in Table 10 . In addition, two days warm spell duration (WSDI2) showed an increasing trend of $0.308^{\circ} \mathrm{C}$ in average (Table 10). Annual mean of minimal relative humidity exhibits an increasing trend at Bohicon station, however annual minimum, maximum, and mean of relative humidity maxima show a decreasing trend running from 0.047 to $0.5 \%$ (Table 11). Annual wind speed at $10 \mathrm{~m}$ altitude showed a slither decreasing trend between 0.007 and 0.025 (Table 11). 
Table 10. Temperature based indices trend.

\begin{tabular}{|c|c|c|c|c|c|c|c|c|c|c|c|c|}
\hline \multirow{2}{*}{ Stations } & \multicolumn{3}{|c|}{ TXn } & \multicolumn{3}{|c|}{ TXx } & \multicolumn{3}{|c|}{ TNn } & \multicolumn{3}{|c|}{ TNx } \\
\hline & Tau & SenSlope & $p$ Value & Tau & SenSlope & $p$ Value & Tau & SenSlope & $p$ Value & Tau & SenSlope & $p$ Value \\
\hline BOHICON & 0.223 & 0.027 & 0.014 & 0.223 & 0.015 & 0.014 & 0.198 & 0.036 & 0.029 & 0.409 & 0.024 & 0.000 \\
\hline COTONOU AIRPORT & 0.403 & 0.037 & 0.000 & 0.219 & 0.020 & 0.016 & 0.067 & 0.013 & 0.459 & 0.394 & 0.025 & 0.000 \\
\hline \multirow{2}{*}{ Stations } & \multicolumn{3}{|c|}{ DTR } & \multicolumn{3}{|c|}{ WSDI2 } & \multicolumn{3}{|c|}{ TX95t } & \multicolumn{3}{|c|}{ TN95t } \\
\hline & Tau & SenSlope & $p$ Value & Tau & SenSlope & $p$ Value & Tau & SenSlope & $p$ Value & Tau & SenSlope & $p$ Value \\
\hline BOHICON & -0.339 & -0.011 & 0.000 & 0.255 & 0.240 & 0.005 & -0.279 & -0.010 & 0.000 & -0.301 & -0.005 & 0.000 \\
\hline COTONOU AIRPORT & -0.286 & -0.012 & 0.001 & 0.297 & 0.375 & 0.001 & -0.309 & -0.006 & 0.000 & -0.302 & -0.006 & 0.000 \\
\hline
\end{tabular}

Table 11. Maxima relative humidity and wind speed at $10 \mathrm{~m}$ altitude trend based on annual minimum, maximum, and mean.

\begin{tabular}{|c|c|c|c|c|c|c|c|c|c|c|c|c|c|c|c|c|c|c|}
\hline \multirow{3}{*}{ Stations } & \multicolumn{10}{|c|}{ Maximal Relative Humidity } & \multicolumn{8}{|c|}{ Wind Speed at $10 \mathrm{~m}$ Altitude } \\
\hline & \multicolumn{3}{|c|}{ Minimum } & \multicolumn{3}{|c|}{ Maximum } & \multicolumn{4}{|c|}{ Mean } & \multicolumn{3}{|c|}{ Minimum } & \multicolumn{3}{|c|}{ Maximum } & \multicolumn{2}{|c|}{ Mean } \\
\hline & Tau & $\begin{array}{l}\text { Sen } \\
\text { Slope }\end{array}$ & $p$ Value & Tau & $\begin{array}{l}\text { Sen } \\
\text { Slope }\end{array}$ & $p$ Value & Tau & $\begin{array}{l}\text { Sen } \\
\text { Slope }\end{array}$ & $p$ Value & Tau & $\begin{array}{l}\text { Sen } \\
\text { Slope }\end{array}$ & $p$ Value & Tau & $\begin{array}{l}\text { Sen } \\
\text { Slope }\end{array}$ & $p$ Value & Tau & $\begin{array}{l}\text { Sen } \\
\text { Slope }\end{array}$ & $p$ Value \\
\hline BOHICON & -0.427 & 0.000 & 0.000 & -0.299 & -0.500 & 0.004 & -0.343 & -0.047 & 0.001 & -0.316 & -0.025 & 0.004 & 0.169 & 0.000 & 0.173 & -0.261 & -0.010 & 0.011 \\
\hline $\begin{array}{c}\text { COTONOU } \\
\text { AIRPORT }\end{array}$ & -0.285 & 0.000 & 0.017 & -0.218 & -0.118 & 0.038 & -0.513 & -0.060 & 0.000 & -0.038 & 0.000 & 0.724 & 0.139 & 0.006 & 0.194 & -0.223 & -0.007 & 0.030 \\
\hline
\end{tabular}


Table 12. Monthly and annual significant trend for sunshine and pan evaporation.

\begin{tabular}{|c|c|c|c|c|c|c|c|c|c|c|c|c|}
\hline \multirow{3}{*}{ Stations } & \multicolumn{6}{|c|}{ COTONOU AIRPORT } & \multicolumn{6}{|c|}{ BOHICON } \\
\hline & \multicolumn{3}{|c|}{ SUND } & \multicolumn{3}{|c|}{ EVA } & \multicolumn{3}{|c|}{ SUND } & \multicolumn{3}{|c|}{ EVA } \\
\hline & Tau & Sen Slope & $p$ Value & Tau & Sen Slope & $p$ Value & Tau & Sen Slope & $p$ Value & Tau & Sen Slope & $p$ Value \\
\hline January & -0.329 & -1.075 & 0.002 & 0.5 & 0.7 & 0.0 & -0.19 & -0.584 & 0.067 & 0.3 & 0.9 & 0.1 \\
\hline February & -0.269 & -0.629 & 0.011 & 0.2 & 0.4 & 0.1 & -0.116 & -0.221 & 0.265 & -0.3 & -0.4 & 0.1 \\
\hline March & -0.178 & -0.521 & 0.094 & 0.4 & 0.6 & 0.0 & 0.017 & 0.029 & 0.876 & -0.1 & -0.1 & 0.7 \\
\hline April & -0.28 & -0.55 & 0.008 & 0.0 & 0.0 & 0.9 & -0.02 & -0.025 & 0.853 & 0.1 & 0.3 & 0.5 \\
\hline May & -0.274 & -0.843 & 0.01 & 0.3 & 0.5 & 0.0 & -0.04 & -0.054 & 0.703 & 0.0 & -0.1 & 0.9 \\
\hline June & -0.167 & -0.56 & 0.116 & 0.3 & 0.6 & 0.0 & -0.193 & -0.407 & 0.063 & 0.0 & -0.1 & 0.9 \\
\hline July & -0.132 & -0.482 & 0.217 & 0.3 & 0.4 & 0.0 & 0.11 & 0.234 & 0.291 & 0.3 & 0.6 & 0.0 \\
\hline August & -0.028 & -0.082 & 0.802 & 0.1 & 0.2 & 0.2 & 0.096 & 0.183 & 0.358 & 0.0 & 0.2 & 0.8 \\
\hline September & -0.03 & -0.048 & 0.786 & 0.1 & 0.2 & 0.3 & 0.154 & 0.339 & 0.14 & 0.0 & 0.0 & 1.0 \\
\hline October & -0.214 & -0.382 & 0.044 & 0.0 & 0.1 & 0.8 & 0.155 & 0.399 & 0.137 & 0.1 & 0.3 & 0.3 \\
\hline November & -0.102 & -0.218 & 0.341 & 0.1 & 0.2 & 0.2 & 0.174 & 0.258 & 0.094 & 0.0 & -0.2 & 0.8 \\
\hline December & 0.073 & 0.181 & 0.496 & 0.5 & 0.8 & 0.0 & 0.293 & 0.677 & 0.005 & 0.3 & 1.0 & 0.0 \\
\hline Annual & -0.445 & -5.278 & 0 & 0.3 & 4.4 & 0.0 & 0.131 & 1.169 & 0.207 & 0.1 & 3.4 & 0.4 \\
\hline
\end{tabular}


At annual scale, Sunshine duration decreased significantly, whereas evaporation increased over Ouémé Delta (Table 12). At the monthly scale, sunshine decreases significantly in the month of January, February, April, May, and October in Cotonou. Pan evaporation increases significantly in the month of January, March, May, June, July, and September in Cotonou.

\subsection{Ouémé Delta Climate Drivers}

As shown in Table 13, the significant variables that positively influence pan evaporation are sunshine duration (SUND), precipitation (PRCP), wind speed (WIND), mean temperature (TMean), and maximum temperature (TMax), decreasingly based on the correlation coefficients. Relative humidity parameters (RH, Hmax, and Hmin) negatively influence pan evaporation in Ouémé Delta. Thus, an increase in relative humidity decrease pan evaporation and vice versa. Dominant climatic variables with more than $10 \%$ absolute value of correlation with pan evaporation are mean relative humidity (RH), maximum relative humidity (Hmax), mean temperature (Tmean), wind speed (WIND), precipitation (PRCP), and sunshine (SUND).

Table 13. Correlation coefficient of pan evaporation with mean relative humidity $(\mathrm{RH})$, maximal relative humidity (Hmax), minimal relative humidity (Hmin), minimal temperature (Tmin), maximal temperature (Tmax), mean temperature (Tmean), wind speed at $10 \mathrm{~m}$ altitude (WIND), precipitation (PRCP), and sunshine duration (SUND).

\begin{tabular}{ccccc}
\hline \multirow{2}{*}{ Climate Variables } & \multicolumn{2}{c}{ COTONOU AIRPORT } & \multicolumn{2}{c}{ BOHICON } \\
\cline { 2 - 5 } & Coef & $p$ Value & Coef & $p$ Value \\
\hline RH & -0.23 & 0.00 & -0.24 & 0.00 \\
Hmax & -0.12 & 0.00 & -0.13 & 0.00 \\
Hmin & -0.07 & 0.00 & -0.04 & 0.00 \\
TMin & 0.02 & 0.00 & 0.01 & 0.12 \\
TMax & 0.04 & 0.00 & 0.12 & 0.00 \\
Tmean & 0.12 & 0.00 & 0.21 & 0.00 \\
WIND & 0.23 & 0.00 & 0.19 & 0.00 \\
PRCP & 0.25 & 0.00 & 0.24 & 0.00 \\
SUND & 0.47 & 0.00 & 0.25 & 0.00 \\
\hline
\end{tabular}

Table 14 showed the relative importance of these dominant climatic variables in pan evaporation. By considering the regression coefficients, mean temperature, sunshine duration, and wind speed have high relationship with pan evaporation at both stations at 0.001 level of confidence.

Table 14. Stepwise regression coefficient of pan evaporation and relative humidity $(\mathrm{RH})$, mean temperature (Tmean), wind speed at $10 \mathrm{~m}$ altitude (WIND), precipitation (PRCP), and sunshine duration (SUND).

\begin{tabular}{|c|c|c|c|c|c|c|c|c|c|}
\hline \multirow{2}{*}{$\begin{array}{l}\text { Climate } \\
\text { Variables }\end{array}$} & \multicolumn{4}{|c|}{ COTONOU AIRPORT } & \multirow{2}{*}{$\begin{array}{c}\text { Climate } \\
\text { Variables }\end{array}$} & \multicolumn{4}{|c|}{ BOHICON } \\
\hline & Coef & $\begin{array}{c}\text { Std. } \\
\text { Error }\end{array}$ & $t$ Value & $\begin{array}{c}\operatorname{Pr} \\
(>|t|)\end{array}$ & & Coef & $\begin{array}{l}\text { Std. } \\
\text { Error }\end{array}$ & $t$ Value & $\begin{array}{c}\operatorname{Pr} \\
(>|t|)\end{array}$ \\
\hline WIND & 0.24 & 0.01 & 28.41 & $0^{* * *}$ & WIND & 0.26 & 0.01 & 20.46 & $0^{* * *}$ \\
\hline SUND & 0.22 & 0.00 & 68.16 & $0 * * *$ & SUND & 0.14 & 0.00 & 31.60 & $0^{* * *}$ \\
\hline Tmean & 0.14 & 0.01 & 19.83 & $0 * * *$ & Tmean & 0.25 & 0.01 & 29.59 & $0^{* * *}$ \\
\hline PRCP & 0.03 & 0.00 & 33.17 & $0 * * *$ & PRCP & 0.03 & 0.00 & 26.25 & $0^{* * *}$ \\
\hline RH & -0.05 & 0.00 & -24.53 & $0 * * *$ & $\mathrm{RH}$ & -0.04 & 0.00 & -17.01 & $0^{* * *}$ \\
\hline
\end{tabular}

At Cotonou Airport, mean temperature, sunshine duration, and wind speed, respectively, explained pan evaporation at 14, 22, and 24\%, as shown on Figure 5. However, at Bohicon, sunshine duration, mean temperature, and wind speed explained pan evaporation, respectively, at 14,25 , and $26 \%$. 
COTONOU AIRPORT

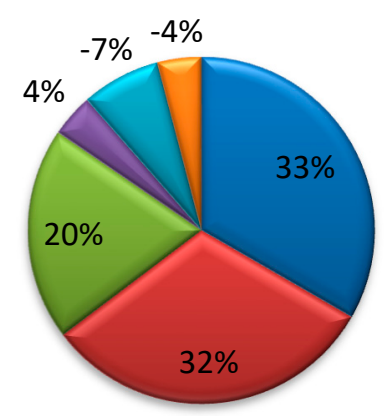

\section{BOHICON}

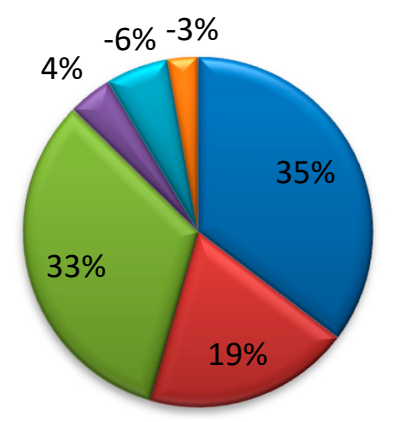

$\square$ Wind speed

$\square$ Sunshine

$\square$ Mean temperature

Precipitation

$\square$ Mean relative humidity

$\square$ Maximum relative humidity

Figure 5. Plot of the percentage of pan evaporation variance hold in each of its explanatory variables.

\section{Discussions}

Heavy and very heavy rainfall extreme increasing trend results are in accordance with Hounkpè et al. [8], which noticed an East West gradient from negative to positive trend in interpolated change rainfall in lower Ouémé catchment. Moreover, annual rainfall trend reduction is also showed in Nigeria by Oguntunde et al. [25], Kabo-bah et al. [6] in Ghana hydropower dam, as well as in Ivory Coast by Soro et al. [4]. However, Simple daily intensity index (SDII) increased with 0.11 slope showing evidence of intensification of heavy rainfall, whereas the contribution from very wet day is almost constant. Even though, annual total precipitation decreased, the amount of rainfall recorded occurs in short period as found by Panthou et al. [2] for West Africa semi-arid regions. This is more visible when trend analysis is conducted at the monthly scale. Thus, the area is experiencing the erratic rainfall announced for the West African coastal area by the intergovernmental panel on climate change in the fifth report [50]. In September, November, and October, Maximum consecutive 10-days rainfall increased significantly, as evidence of rainfall intensification, especially in the high water period over the Delta, as shown by Hounkpè et al. [8] over Ouémé Basin. These change in rainfall extreme indices trends will impact extreme events like flood occurrence, as noticed by Nka et al. [51] and Guhathakurta et al. [52]. In addition, the increasing trend in air temperature as result of global warming experienced in Ouémé Delta was predicted by the Intergovernmental Panel on Climate Change, with impacts on irrigated land and then reducing agricultural yield that is sensitive to water availability [20]. Though, the change in temperature noticed in this paper are slither, the overall country experienced an increase of $1.1^{\circ} \mathrm{C}$ since 1960, as mentioned by Bodegom et al. [53]. Pan evaporation as key element in surface water resource management has been taken together with rainfall, sunshine duration, relative humidity, wind speed, as well as temperature to detect those to which it is sensitive. Results showed that most significant explainers of pan evaporation detected here are also found in Chinese Lower Yellow River Basin for the period 1961 to 2010 by Xing-Jie et al. [24]. In fact, combined effects of decrease in wind speed and sunshine duration with an increase in mean temperature are the main causes for decrease in pan evaporation in that area. Moreover, Sun radiation, wind speed, and vapor pressure deficit were found to be explanatory variables of pan evaporation in Ibadan in Nigeria over the period of 1973-2008 using principal component analysis for variable selection by Oguntunde et al. [25]. In fact, they showed that sun radiation, wind speed, and vapor pressure deficit, respectively, explained pan evaporation variance at 30, 15, and $6 \%$. The main explanatory variables of pan evaporation found in this study are the same as those of Liu et al. [49]. In fact, they found daily temperature range, sunshine duration, and average wind speed to be the main influencing factors of pan evaporation, and even the determinative factors of its trend. However, air temperature and vapor pressure are the major factors impacting pan evaporation in Zoige Plateau alpine wetland of eastern Tibetan region Zhao et al. [54]. Thus, despite the difference in climate variables considered in searching for pan evaporation influencing factors, wind speed, sunshine duration, and temperature are found to be the main drivers of pan evaporation. An increase in temperature and pan evaporation combined with decrease in wind speed could increase heat 
stress in plant, as shown by Hoffman et al. [55]. Consequently, such situation could favor livestock migration and then trigger conflict between farmers, as observed in West African regions and noticed by Touré et al. [20]. Furthermore, increase in temperature and flood event will also positively impact on the spread of infectious diseases, like malaria, which accounts for about $41 \%$ of all visits to health facilities in Bénin [56]. In fact, more standing water will increase the habitats for malaria vectors that are mosquito, whereas increased temperatures and prolonged dry seasons will have the potential to extend the vector's seasonal window, exposing human population at risk to this disease.

\section{Conclusions}

This work analyzed trends in rainfall and temperature extremes, as well as pan evaporation influencing factors over Ouémé Delta in Bénin. Fifteen rainfall based climate indices; eight temperature based indices as well as minimal relative humidity, maximal relative humidity, sunshine duration, wind speed at $10 \mathrm{~m}$ altitude, and pan evaporation at annual scale were computed at eight gauging stations (including two synoptic stations) from 1960 to 2016. Prewhitened Mann-Kendal method furthered trend detection over Ouémé Delta, especially at the monthly scale. Results showed intensification in heavy rainfall frequency with increase in monthly maximum precipitation in the months of September, October, and November, which constitute the high water period in Ouémé Delta. Furthermore, explanatory climatic variables that influence pan evaporation in this area are wind speed, mean temperature, and sunshine duration, with wind speed and sunshine explaining its variance at almost $50 \%$. Some of the trends are now detected due to the prewhitened Mann-Kendall method that removed the internal serial correlation comparatively to previous work. As results showed a clear increase in extreme rainfall, especially heavy, very heavy rainfall, maximum consecutive 1, 2, 3, 5, and 10-day maximum, it will probably impact flood event in damages and losses in Ouémé Delta. Most impacted areas will be those with positive trends and are found to be the closest to Ouémé Delta. An increase in temperature as a consequence of global warming and a decrease in relative humidity is going to put stress on plants in terms of water availability. Water loss in rivers is basically measured using pan evaporation. In this work, pan evaporation showed a significant increasing trend given evidence of an increase in surface water loss over Ouémé Delta River and ponds. Consequently, water availability issue is going to be problematic with rise in conflicts between farmers because of livestock migrations that is already observed in West Africa. Furthermore, a decrease in surface water combined with increasing temperature will result in the loss in biodiversity and ecosystem production function in Nokoué Lake. With an increase in frequent extreme rainfall events, an early warning system has to be well set for Ouémé Delta, the food basket of Southern Bénin for damages and losses prevention. In addition, with an increase in surface water evaporation, actions have to be taken for efficient water usage. For instance, clipping dam in the upper stream of Ouémé Delta could help in overflow water storage for future use, like irrigation. In addition, health facilities should be developed and well equipped to cater for needs.

Author Contributions: R.H., A.E.L., S.M. and A.A.A. designed this work. R.H. performed field work, the data collection and computation while A.E.L., S.M. and A.A.A. contribute to results analysis and interpretation.

Funding: This work has been funded by the German Federal Ministry of Education and Research (BMBF) through the West African Science Service Centre on Climate Change and Adapted Land Use (WASCAL) Scholarship Program. The authors then acknowledge the BMBF for this great support.

Conflicts of Interest: The authors declare no conflict of interest.

\section{References}

1. Oguntunde, P.G.; Friesen, J.; Van De Giesen, N.; Savenije, H.H.G. Hydroclimatology of the Volta River Basin in West Africa: Trends and variability from 1901 to 2002. Phys. Chem. Earth 2006, 31, 1180-1188. [CrossRef]

2. Panthou, G.; Lebel, T.; Vischel, T.; Quantin, G.; Sane, Y.; Ba, A.; Ndiaye, O.; Diongue-Niang, A.; Diopkane, M. Rainfall intensification in tropical semi-arid regions: The Sahelian case. Environ. Res. Lett. 2018, 13, 064013. [CrossRef] 
3. Nouaceur, Z.; Murărescu, O. Rainfall Variability and Trend Analysis of Annual Rainfall in North Africa. Int. J. Atmos. Sci. 2016, 2016, 1-12. [CrossRef]

4. Soro, G.E.; Noufé, D.; Albert, T.; Bi, G.; Shorohou, B. Trend Analysis for Extreme Rainfall at Sub-Daily and Daily Timescales in Côte d' Ivoire. Climate 2016, 4, 1-15. [CrossRef]

5. Oguntunde, P.G.; Abiodun, B.J.; Lischeid, G. Rainfall trends in Nigeria, 1901-2000. J. Hydrol. 2011, 411, 207-218. [CrossRef]

6. Kabo-bah, A.T.; Diji, C.J.; Nokoe, K.; Mulugetta, Y.; Obeng-ofori, D.; Akpoti, K. Multiyear Rainfall and Temperature Trends in the Volta River Basin and their Potential Impact on Hydropower Generation in Ghana. Climate 2016, 4, 1-17. [CrossRef]

7. Hountondji, Y.; Ozer, P. Trends in extreme rainfall events in Benin (West Africa), 1960-2000. In Proceedings of the 1st International Conference on Energy, Environment And Climate Changes, Ho Chi Minh City, Vietnam, 26-27 August 2011; pp. 1-7.

8. Hounkpè, J.; Diekkrüger, B.; Badou, D.; Afouda, A. Change in Heavy Rainfall Characteristics over the Ouémé River Basin, Benin Republic, West Africa. Climate 2016, 4, 15. [CrossRef]

9. Attogouinon, A.; Lawin, A.E.; M'Po, Y.N.; Houngue, R. Extreme Precipitation Indices Trend Assessment over the Upper Ouémé River Valley-(Bénin). Hydrology 2017, 4, 36. [CrossRef]

10. N’Tcha M'Po, Y.; Lawin, E.; Yao, B.; Oyerinde, G.; Attogouinon, A.; Afouda, A. Decreasing Past and Mid-Century Rainfall Indices over the Ouémé River Basin, Benin (West Africa). Climate 2017, 5, 74. [CrossRef]

11. Lawin, E.A.; Afouda, A.; Oguntunde, P.G.; Gosset, M.; Lebel, T. Rainfall variability at regional and local scales in the Ouémé upper valley in Benin. Int. J. Sci. Adv. Technol. 2012, 2, 46-55.

12. Marchand, M.; Bucx, T.; Makaske, B.; van de Guchte, C.; van Driel, W. Enabling Delta Life-What makes managing land and water in deltas different? Discussion paper. Delta Alliance GWP 2012, 48.

13. Mynett, A.E.; Vojinovic, Z. Hydroinformatics in multi-colours-part red: Urban flood and disaster management. J. Hydroinformatics 2009, 3-4, 166-180. [CrossRef]

14. United Nations. Economic Commission for Africa. In African Water Development Report 2006; United Nations: Addis Ababa, Ethiopia, 2006.

15. IEG World Bank. Responding to Floods in West Africa: Lessons from Evaluation; IEG World Bank: Washington, DC, USA, 2010.

16. Bojang, F.; Ndeso-Atanga, A. Economic and social significance of forests for Africa's sustainable development. Nat. Faune Enhancing Nat. Resour. Manag. Food Secur. Africa 2011, 25, 2016.

17. IPCC. Climate Change 2007: Synthesis Report. Contribution of Working Groups I, II and III to the Fourth Assessment Report of the Intergovernmental Panel on Climate Change; Core Writing Team, Pachauri, R.K., Reisinger, A., Eds.; Intergovernmental Panel on Climate Change: Geneva, Switzerland, 2007; ISBN 92-91.

18. Diedhiou, A.; Bichet, A.; Wartenburger, R.; Seneviratne, S.I.; Rowell, D.P.; Mouhamadou, S.B.; Diallo, I.; Todzo, S.; Touré, N.E.; Camara, M.; et al. Changes in climate extremes over West and Central Africa at $1.5^{\circ} \mathrm{C}$ and $2{ }^{\circ} \mathrm{C}$ global warming. Environ. Res. Lett. 2018, 13, 1-11. [CrossRef]

19. Cook, K.H.; Vizy, E.K. Impact of climate change on mid-twenty-first century growing seasons in Africa. Clim. Dyn. 2012, 39, 2937-2955. [CrossRef]

20. Touré, H.A.; Kalifa, T.; Kyei-Baffour, N. Assessment of changing trends of daily precipitation and temperature extremes in Bamako and Ségou in Mali from 1961-2014. Weather Clim. Extrem. 2017, 18, 8-16. [CrossRef]

21. Niang, I.; Ruppel, O.C.; Abdrabo, M.A.; Essel, A.; Lennard, C.; Padgham, J.; Urquhart, P. Africa, Climate Change 2014: Impacts, Adaptation, and Vulnerability. Part B: Regional Aspects. Contribution of Working Group II to the Fifth Assessment Report of the Intergovernmental Panel on Climate Change; Barros, V.R., Field, C.B., Dokken, D.J., Eds.; Cambridge University Press: New York, NY, USA , 2014; pp. 1199-1265.

22. Nicholson, S.E.; Dezfuli, A.K. The Relationship of Rainfall Variability in Western Equatorial Africa to the Tropical Oceans and Atmospheric Circulation. Part I: The Boreal Spring. J. Clim. 2013, 26, 45-65. [CrossRef]

23. New, M.; Hewitson, B.; Stephenson, D.B.; Tsiga, A.; Kruger, A.; Manhique, A.; Gomez, B.; Coelho, C.A.S.; Masisi, D.N.; Kululanga, E.; et al. Evidence of trends in daily climate extremes over southern and west Africa. J. Geophys. Res. Atmos. 2006, 111, 1-11. [CrossRef]

24. Xing-Jie, J.; Ji-Jun, W.; Wan-Long, G.; Ye-Yu, Z.; Feng-Xiu, L. Trends in Annual and Seasonal Pan Evaporation in the Lower Yellow River Basin from 1961 to 2010. Adv. Clim. Chang. Res. 2012, 3, 195-204. [CrossRef]

25. Oguntunde, P.G.; Abiodun, B.J.; Olukunle, O.J.; Olufayo, A.A. Trends and variability in pan evaporation and other climatic variables at Ibadan, Nigeria, 1973-2008. Meteorol. Appl. 2012, 19, 464-472. [CrossRef] 
26. Djaman, K.; Koudahe, K.; Ganyo, K.K. Trend Analysis in Annual and Monthly Pan Evaporation and Pan Coefficient in the Context of Climate Change in Togo. J. Geosci. Environ. Prot. 2017, 5, 41-56. [CrossRef]

27. Zhang, Q.; Wang, W.; Wang, S.; Zhang, L. Increasing trend of pan evaporation over the semiarid loess plateau under a warming climate. J. Appl. Meteorol. Climatol. 2016, 55, 2007-2020. [CrossRef]

28. Helfer, F.; Lemckert, C.; Zhang, H. Impacts of climate change on temperature and evaporation from a large reservoir in Australia. J. Hydrol. 2012, 475, 365-378. [CrossRef]

29. Roudier, P.; Ducharne, A.; Feyen, L. Climate change impacts on runoff in West Africa: A review. Hydrol. Earth Syst. Sci. 2014, 18, 2789-2801. [CrossRef]

30. Mbaye, M.L.; Hagemann, S.; Haensler, A.; Stacke, T.; Gaye, A.T.; Afouda, A. Assessment of Climate Change Impact on Water Resources in the Upper Senegal Basin (West Africa). Am. J. Clim. Chang. 2015, 4, 77-93. [CrossRef]

31. Vinet, L.; Zhedanov, A. A “missing” family of classical orthogonal polynomials. J. Phys. A 2011, 44, 085201. [CrossRef]

32. Urama, K.C.; Ozor, N. IMPACTS OF CLIMATE CHANGE ON WATER RESOURCES IN AFRICA: The Role of Adaptation. African Technol. Policy Stud. Netw. 2010, 1-29.

33. BOUCHARDEAU, A.; BAUDUIN, D. MONOGRAPHIE DU DELTA DE L'OUÉMÉ; ORSTOM: Paris, France, 1964.

34. Le Barbe, L.; Ale, G.; Millet, B.; Texier, H.; Borel, Y.; Gualde, R. Les Ressources en Eaux Superficiels de la République du Bénin; ORSTOM: Paris, France, 1993; ISBN 270990344X.

35. Mama, D. Méthodologie et résultats du diagnostic de l'eutrophisation du lac Nokoue (Bénin). 2010. Available online: http:/ / www.sudoc.abes.fr/DB=2.1/SRCH?IKT=12\&TRM=150214936 (accessed on 23 December 2018).

36. Herold, N.; Alexander, L.V. ClimPACT: Software for quantifying climate extremes for sector applications. 2016. Available online: https://www.wmo.int/pages/prog/wcp/ccl/opace/opace4/documents/ClimPACT_ poster.pdf (accessed on 23 December 2018).

37. Searcy, J. K.; Hardison, C. H. Double-Mass Curves; United States Government Printing Office: Washington, DC, USA, 1960.

38. Tank, A.M.G.K.; Zwiers, F.W. Guidelines on Analysis of Extremes in a Changing Climate in Support of Informed Decisions for Adaptation; WMO: Geneva, Switzerland, 2009.

39. Mann, H.B. Nonparametric tests against trend. J. Econom. Soc. 1945, 13, 245-259. [CrossRef]

40. Kendall, M.G. Ranks and Measures. Biometrika 1962, 49, 133-137. [CrossRef]

41. Patakamuri, S.K.; Brien, N.O. Modified Mann Kendall Trend Tests. 2018.

42. Tabari, H.; Somee, B.S.; Zadeh, M.R. Testing for long-term trends in climatic variables in Iran. Atmos. Res. 2011, 100, 132-140. [CrossRef]

43. Salmi, T.; Maatta, A.; Anttila, P.; Airola, T.R.; Amnell, T. Detecting Trends of Annual Values of Atmospheric Pollutants by the Mann-Kendall Test and Sen's Slope Estimates: The Excel Template Application Makesens; Finnish Meteorological Institute: Helsinki, Finland, 2002.

44. Yue, S.; Pilon, P.; Phinney, B.; Cavadias, G. The influence of autocorrelation on the ability to detect trend in hydrological series. Hydrol. Process. 2002, 16, 1807-1829. [CrossRef]

45. Serinaldi, F.; Kilsby, C.G. The importance of prewhitening in change point analysis under persistence. Stoch. Environ. Res. Risk Assess. 2016, 30, 763-777. [CrossRef]

46. Blain, G.C. The Mann-Kendall test: The need to consider the interaction between serial correlation and trend. Acta Sci. 2013, 35, 393-402. [CrossRef]

47. Bayazit, M.; Önöz, B. To prewhiten or not to prewhiten in trend analysis? Hydrol. Sci. J. 2007, 52, 611-624. [CrossRef]

48. Yue, S.; Wang, C.Y. Applicability of Prewhitening to Eliminate the Influence of Serial Correlation on the Mann-Kendall Test. Water Resour. Res. 2002, 38. [CrossRef]

49. Liu, C.; Zhang, J.; Wang, G.; He, R. Changes of pan evaporation and its influencing factors in different climate zones of China. In Proceedings of the Symposium J-H02 Held during IUGG2011, Melbourne, Australia, 28 June-7 July 2011; 2011; pp. 93-98.

50. Woodward, A.; Smith, K.R.; Campbell-Lendrum, D.; Chadee, D.D.; Honda, Y.; Liu, Q.; Olwoch, J.; Revich, B.; Sauerborn, R.; Chafe, Z.; et al. Climate change and health: On the latest IPCC report. Lancet 2014, 383, 1185-1189. [CrossRef] 
51. Nka, B.N.; Oudin, L.; Karambiri, H.; Paturel, J.E.; Ribstein, P. Trends in floods in West Africa: Analysis based on 11 catchments. Hydrol. Earth Syst. Sci. 2015, 19, 4707-4719. [CrossRef]

52. Guhathakurta, P.; Sreejith, O.P.; Menon, P.A. Impact of climate change on extreme rainfall events and flood risk in India. J. Earth Syst. Sci. 2011, 120, 359-373. [CrossRef]

53. Van Bodegom, A.J.; Satijn, B. Climate Change Profile Benin; Netherlands Commission for Environment Assessment: Utrecht, The Netherlands, 2015.

54. Zhao, N.; Gou, S.; Zhang, B.; Yu, Y.; Han, S. Changes in Pan Evaporation and Their Attribution to Climate Factors in the Zoige Alpine Wetland, the Eastern Edge of the Tibetan Plateau (1969-2014). Water 2017, 9, 971. [CrossRef]

55. Hoffman, M.T.; Cramer, M.D.; Gillson, L.; Wallace, M. Pan evaporation and wind run decline in the Cape Floristic Region of South Africa (1974-2005): Implications for vegetation responses to climate change. Clim. Change 2011, 109, 437-452. [CrossRef]

56. Ganfon, H.; Diallo, T.; Nanga, C.; Coulibaly, N.; Benao, V.; Ekanmian, G.; Sandouidi, A. Private pharmacy staff in five main towns in Benin, Burkina Faso and Mali: Knowledge and practices concerning malaria care in 2014. Med. Sante Trop. 2017, 27, 164-169. [PubMed]

(C) 2018 by the authors. Licensee MDPI, Basel, Switzerland. This article is an open access article distributed under the terms and conditions of the Creative Commons Attribution (CC BY) license (http:/ / creativecommons.org/licenses/by/4.0/). 